\title{
Evaluation of Public Tender Law Changes in Turkey in Context of Economic Sustainability
}

\author{
Dr. Nihal Arda AKYILDIZ \\ Firat University, Faculty of Architecture, Department of Architecture, 23119, Elazığ Turkey
}

\begin{abstract}
In today's economic system, the state has to make some purchases of goods and services to produce and offer the services of the public system formed by local administrations and other administrations. These purchases are the purchases that the public deems necessary through the private sector within the framework of investment programs and budget. Although annual growth and the tranches of spending items in investment programs change every year within the framework of the country's growth, purchases in the public system necessarily occur depending on these rates. Regulations and improvements on this subject; will not only affect the current levels of economic and social welfare, but will also increase the welfare levels of future generations and will support economic sustainability. The issue of public purchases regulated by law, which has become more important especially with its wide coverage in the Eleventh Development Plan, continues to contribute to economic sustainability with its value that directs the country's economy.

In the study, literature reviews of public procurements, tender laws and related regulations which have a direct effect on the country's economy were conducted as method; and changes in the public procurements, tender laws and relevant legislation have been aimed to be revealed. Since the first law of 1925, in the four law amendments, some regulations have been made abiding by the main principles and the arrangements required by the country have been made. While the names of the procurement procedures change in the laws are partial, the main contents are preserved. The study examines the four procurement laws that have changed in this way; aiming to provide information on the subject and to address the forecasts that are realized with the support of the country's economy and sustainable development.
\end{abstract}

Keywords: Tender law, public procurement legislation, economic sustainability, sustainable development, procurement procedures and implementing regulations

\section{Introduction}

The wars and economic crises affecting country economies all over the world made it inevitable for states to intervene in their own economies through fiscal policies in order to direct public resources. The economic movement started with the transition to liberal economies in the beginning of the 20th century, but the positive effects on the economy were short-lived due to the simultaneous social changes and social problems.

Industrialization, modernization, urbanization and following migration events required some compensations in the social and economic structure. While the state tried to cover the expense items that it had to serve, with the understanding of a social state in line with the budget for the interests of the country, the rapidly increasing public expenditures showed a great increase in the gross domestic product. As a result of these major transformations that started in the beginning of the 20th century, the ratio of public spending by the state to gross domestic product in the developing countries was $10 \%$ in the past, while it reached $27 \%$ in the 1960s and 50\% in the 1990s (Kanca and Bayrak, 2015). The responsibility of the state to organize the social, economic and cultural structure has organized and managed this process with the public procurement or expenditure' item from the budget it has obtained with public revenues. The argument required for the healthy execution of this system was the public procurement market and the tender legislation developed in parallel. 
Public bodies need to meet public expenditures that they have to use effectively and efficiently to meet the goods, services or works they need with a system supported by ideal and strong rules. Therefore, public tender legislation, which is of great importance; always needs to carry out the delivery of the goods and services in the quality and standards required for the tender markets with a healthy system that prevents abuse without any problems.

The increase of the appropriations allocated to the construction sector in the investment programs every year, which is the center of gravity of Turkey's economy; required to increase the quality and competition environment of the procurement of goods and services, construction works, contracting and technical consultancy services and thus the regulations regarding the tender legislation have become more and more important. For this reason, the subject of the study is the construction, service and goods procurement sector, which is an important parameter in the economic sustainability and development criteria of the country, and accordingly, arrangements that vary according to the supply / demands of the period in the tender legislation. It can be observed that Public Tender Laws 661, 2490, 2886 and finally 4734, which were regulated with the demands needed, include bidding or underbidding by closed envelope, closed envelope, and open tender (Çetinkaya et al., 2018). As a method in the study; the procurement laws examined by the literature review, and the historical process of the transformation projections planned with the revisions aimed at eliminating the problems experienced in the period of application and compensating the deficiencies by contributing to the economic sustainability were examined in terms of the laws.

\section{Relationship Between Economic Sustainable Development and Tender Laws}

The concept of sustainability, has increased its value on the agenda almost every day since 1970's. While the concept strengthens the potential of this generation to meet its needs, it includes the process of realizing the potential that does not compromise the ability of future generations to meet their own needs (Bruntland Report, 1987). These values that are requied to be transfered to next generations; ecosystems, contain healing processes that can be achieved in spatial space, cultural, management, services, energy and economic areas, that is, in all of life (Altuntaş, 2012:137). While sustainability contributes to meeting the needs of the current generation, without jeopardizing the needs of future generations; it includes the idea of guaranteeing continuity. It should be considered as a multidisciplinary concept that strives to maintain balanced social, economic and ecological systems and it requires the participation of society at all ages / levels (Benkari, 2013).

In studies on sustainability, economic and social sustainability are also considered as non-independent components as well as environmental issues (UNESCO-MOST, 1996). These components are mutually supportive and they are issues that should be addressed as a whole in achieving sustainable development goals (Karakurt Tosun, 2013:33).

According to the sustainable development approach, if there is a cooperation between environmental policies and economic policies, development will occur with an improvement in the social structure. In this context, the environmental sustainability dimension of sustainable development; includes conservation of natural resources and increasing human welfare while meeting human needs. Economic sustainability, which is an important second dimension; requires a strong non-governmental organization with stable economic participation. The last component, which is the social sustainability dimension, includes the stability of economic capital, and the social welfare (Goodland, 1995:17), (Karakurt Tosun, 2009). Along with the flow of modern life that has been changing from the past to the present, technological developments, social and economic changes have transformed the living standards of people as well as their understanding of welfare (Ehrenfeld, 2008). Sustainability is a development model aiming at high efficiency by providing continuous, perpetual and uninterrupted continuity - the optimal conditions of efficiency of any system- for many years in the environmental, economic or social sense. With this quality, the concepts of economic and social development have been replaced by the concept of sustainable development. The concept of sustainable development is generally addressed in three dimensions:

- Economic Sustainable Development: Includes the ability to produce goods and services on an ongoing basis, continuity of public manageability, and uninterrupted execution of agricultural and industrial production, 
- Environmental Sustainable Development: Includes the protection of the natural, environmental and renewable resource systems, as well as the protection of the entire ecosystem with atmospheric balance and biodiversity,

- Social Sustainable Development: Refers to adequate provision of social services, including health, education and participation, along with gender, age and all other egalitarian delivery mechanisms of public services with political responsibility (Holmberg and Sandbrook, 1992).

To achieve sustainable social development, choices should be made by strengthening the relation between the 'three E', which are the concepts of 'economy, ecology and equality'. The ability of economic activities to self-renew for serving common interests should generate an atmosphere of economic confidence while creating local wealth. Similarly, 'equality', which is a component of this concept, is the equal opportunity of social decision making, participation and utilization processes in all activities (At1l et al, 2005:218). In this context, the issue was handled within the framework of development, causing political and ideological discussions.

Considering the issue with a cultural, social, economic and political perspective, with the idea that future generations have a right to the values that society has today; Economic sustainability is of great importance in social life, as it is believed that the values owned should be passed from generation to generation 'continuously and without interruption'. The tender laws that can ensure economic sustainability, with the capacity to affect the economic structure in the country, the gross national product; and not only this generation but also future generations in terms of economic structure and development criteria, triggers the economic development of the country. In this context, when the subject is desired to be reviewed, it is necessary to analyze which development processes the tender laws witnessed from the past to the present.

\section{Historical Process of Public Tender Law in Turkey}

After the foundation of the Republic, with the establishment of the Constitution to rule the country; laws have been made to meet the needs of public institutions and organizations in order to ensure that the practices are manageable. The first tender law of the Republic, which regulates public procurement, with the Official Gazette No. 97 dated April 28, 1925 (Tender School) '661 Auction, Debate and Import Law' was put into practice. The first law was consisted of '26 Articles'. In the purpose and scope of the law;

Article 1 - 'Bidding or underbidding to provide all kinds of purchases, sales, rental construction and repairs and explorations and manufacturing (production) and operation, transportation and similar works to be done on behalf of the Administration are made by closed envelope method. In the cases listed below, bargaining is suitable for situations covered in the eighteenth article, auction or reduction is suitable for the works shown in the sixteenth article, while the construction of the Public Works and the operating orders can be made by bailment method on the condition of being based on a special law'.

Article 2 - 'The specification document that collects all details of the goods or work to be auctioned or reducted will be determined and summarized at the beginning, as well as an approved copy will be given to everyone that states they are willing to participate in auction or reduction from the declaration of the start' is phrased.

The Tender Law No. 661 is the continuation of the regulation issued in 1857 and a new regulation added in 1921 on public purchases and tenders in the Ottoman period.

In a new regulation added in 1921, it was envisaged to meet the needs of public institutions in the center and branches in Istanbul together with military institutions that exceed of 500 Liras, through the "Tevhid-i Mubayat" commission established under the Ministry of Finance.

The name of the tender, which is carried out by auction and reduction, which is the basis of the law, is named as closed envelope method. While this Law remained in force, it was amended by laws numbered 779, 878, 1330, 1540 and 2338 in line with the needs, but it did not exactly meet the needs (Y1lmaz, 2007); and it remained in effect until 1934, as the changes made over time did not meet the public needs even though they were added.

According to the provisions and conditions of the day, the second tender law dated 02 June 1934 came into force as 2490 numbered Auction and Reduction Law. This law, which was taken from France, has a structure supporting competition in which the bid is determined by underbidding for the public purchases 
and by bidding for the sales. The second law was consisted of 73 Articles. In the purpose and scope of the law;

Article 1 - 'Buying, selling, having, discovering, leasing, renting and other similar works of departments directed by public, appendant and private budgets are done in accordance with the provisions of this law.

However, it is not obligatory to apply the provisions of this law in works other than the construction and essential repairs of the institutions that more than half of its capital is owned by the State, and of such departments and institutions and their affiliated capital entities in accordance with the provisions of their private laws.

Article 2 - In order to be able to enter the auction and reduction works in accordance with this law, it is necessary to bring forward the required guarantee and, if required, present the documents written in this law along with having legal residence' phrases are included.

In the Law No. 2490, the lowest price was started to be applied as the suitable price. Seeing that the lowest price causes negative results in terms of duration, cost and quality, the lowest price usually costs much more than the most expensive offer in construction works. Since such examples are common, some changes are foreseen to use public resources effectively and efficiently. The monetary limits included in the 41st, 46th and 50th articles of the Auction Reduction and Procurement Law No. 2490 were increased by Law No.4876 dated 24 April 1946. Later, with the authorization granted by Law No. 2171, Law No. 4876 was abolished by the Decree Law No. 22 dated 26.01.1979 and many articles of the law were changed. Despite everything, Law No. 2490 remained in effect until 1983. Although few changes were made and the law remained in force for a long time, its inelastic provisions could not meet the needs of the period. A new law has been prepared on the grounds that the system will be implemented safely for the planned period.

The State Procurement Law No. 2886, published in the Official Gazette No. 18161 and dated September 10, 1983, came into force as the third procurement law of the state (TBMM, 1981). The third law was consisted of 96 main articles and 4 temporary articles, and remained in force until 2002. In the purpose and scope of the law;

Article 1 - 'Buying, selling, service, construction, rent, tramping, in-kind rights establishment and transportation of property works of administrations with general budget or annexed budget and municipalities, are carried out in accordance with the provisions written in this Law. Performing method of works of the above-mentioned administrations listed in the first paragraph and institutions established by the circulating capital affiliated to the departments or funds authorized by special laws is specified by regulation to be issued by the President.

Article 2 - 'In the execution of this Law, it is essential to meet the needs in the best way, under appropriate conditions and on time and to ensure openness and competition in the tender. Various works that are customary to be met by different bidders cannot be collected in a reduction tender. However, by declaring that the tenders will be made separately, their announcements might be made altogether. The works constituting the subject of the tender cannot be divided into sections in order to benefit from the cases written in this Law. However, if there are no applicants, it is possible to divide important works into parts that will not change the method of the purchase' phrases are included.

The Tender Law No. 2886 did not respond adequately to the changing needs of the period (TBMM, 2001), and there were cases when it was insufficient to solve the problems and failures that occurred during the implementation phase. There were some problems in the State Tender Law No. 2886, these were;

- Confusion and problems arising from the fact that many public institutions and organizations were out of public procurement legislation in the implementation of the Law,

- Despite all public administrations were under the same tender law; the administrations were forming tender regulations in line with their wishes,

- Although it is mandatory to make announcements in local or national media for the tenders to be held and the duration of the announcements is determined by law; administrations were creating an 
environment where competitive participation can be prevented by adjusting the announcement timings according to their own wishes,

- The criteria that should be included in the tender announcements are excluded in the announcement and the principle of equal treatment in the tender evaluation process is damaged,

- Failure to establish certain standards in terms of tender practices, procedures and documents of public contracting administrations,

- The responsibility of the administration carrying out the tender is not wide enough, and accordingly, the information need of the public is not fully met,

- The tenderers who have a certain economic and financial along with professional and technical competence have limited means to participate in tenders due to the provisions in the tender rules,

- An audit and follow-up unit specially responsible for public procurement could not be established,

- The absence of an administrative procedure and a decision-making higher administration for the process of examining and evaluating the complaints of the bidders about public tenders,

- The administrations negligence to inform other firms participating in the tender about the results of the tender,

- The public procurement application made with the relevant regulations and other regulations is not in compliance with the international standards and cannot be in parallel with up-to-date developments,

- Failure to fully achieve the expected benefit from public spending due to insufficient openings to competition, transparency principles and objective criteria,

- Encountering problems such as not informing the companies participating in the tender and the public sufficiently, due to the fact that the authority and responsibility of the administration and the public officials who carry out the tender are limited,

- 'Tender commission will be convened completely' is regulated, but if the elected member does not participate in the tender, there are some hesitations about whether the tender can be held or not due to the fact that a substitute member does not exist,

- The uncertainty of whether there is an appropriation from the national budget for the works put out to tender or not,

- Leaving the environmental impact assessment (EIA) report at the location of the tender to the tender result,

- The price being known by all participants in the tenders,

- Despite the fact that the law was issued to cover 'sales, service, construction, rent, tramp, property establishment and transportation of property', the difficulties experienced in making public expenditures; along with the issues of sales, leasing, tramping and ownership are aimed at generating income to the public,

-The law does not cover all public institutions and is not compatible with the European Union in terms of international tender practices,

- The public procurement law and public procurement contract laws need to be handled within the scope of separate laws, due to several issues born during application, multiple tasks of various nature such as the arrangement of purchasing, selling, service, construction, rent, tramping, property inheritance and transportation of the property covered in the same law.

Accordingly, as the fourth and last tender law, Public Procurement Law No. 4734 and Public Procurement Contracts Law No. 4735 were prepared. Public Procurement Law No. 4734 was adopted on 04.01.2002 and entered into force with the Official Gazette No. 24648 dated January 22, 2002 (TBMM, 2003). In the purpose and scope; 
Article 1-'The purpose of this Law is to determine the principles and procedures to be applied in the tenders to be made by public institutions and organizations under public law or under the control of the public or using public resources.

Article 2- The procurement of goods or services and construction works procured from any source used by the administrations specified below are executed in accordance with the provisions of this Law' phrases are included.

The Fourth Public Procurement Law consists of 6 sections and 70 main articles. The date of acceptance of the Public Procurement Contracts Law No. 4735 was 05.01.2002, and it came into force with the Official Gazette No. 24648 dated 22 January 2002. Aim and scope;

Article 1-'The purpose of this Law is to determine the principles and procedures regarding the issuance and implementation of contracts in accordance with the Public Procurement Law.

Article 2 - This Law covers the contracts issued as a result of the tenders made by the institutions and organizations subject to the Public Procurement Law in accordance with the provisions of the said Law' phrases are included.

The Fourth Public Procurement Contracts Law consists of 5 sections and 41 main articles. The main basis of all these Laws lies in meeting the needs of the state in the most favorable conditions, on time, by taking into consideration the principles of openness and competition (İğdeler, 2003). All changes that have to be made during the stage of our country becoming a full member to European Union have been reviewed. In the tender system, the necessity of resolving the problems arising from the fact that the tendering process of public spending and the implementation processes of the tenders were gathered under separate laws. Accordingly, various amendments were made in the administrative and legal fields, and compliance laws were enacted respectively.

In this context, the Public Procurement Law numbered 4734 and the Public Procurement Contracts Laws numbered 4735 were inevitable in order to bring the existing legislation in line with the current conditions. The Public Procurement Law No. 4734 and the Public Procurement Contracts Law No. 4735 have been enacted as of 01.01.2003. However, the Public Procurement Law, which has been changed frequently since its entry into force, has undergone 186 amendments with 50 Laws and Decree Laws with the last update. The subject where most of the revisions is made in the law is "exceptions", that is, works that fall outside the scope of the law. Public procurement law No. 4734 excluded some public procurements, as in Law No. 2886. Some purchases of these administrations, which are within the scope of the Public Procurement Law, are excluded from other articles of this law, except for penalty and prohibition provisions. These purchases are:

a) Procurement of agricultural or animal husbandry products made directly from producers or partners in order to process, utilize, improve or sell in accordance with the establishment purpose or legislation, and procurement of services from forest villages development cooperatives and villagers pursuant to the Forest Law No. 6831,

b) Purchases of goods and services and works related to defense, security or intelligence areas or related to situations that require special security measures or confidentiality during the execution of the contract or that require the protection of basic interests related to state security, which are decided by the relevant ministry,

c) Purchases of goods or services and construction works that will be done by external financing provided in accordance with international agreements and tasks that it is stated in the financing agreement that different tender procedures and principles will be applied; all kinds of consultancy and credit rating services for borrowings from international capital markets; purchases of goods or services related to the production and printing of banknotes and precious documents of the Central Bank of the Republic of Turkey and procurement of any consultancy services to be made within the framework of Law No. 4046 dated 24.11.1994 for privatization applications; purchases of goods and services related to the commercial activities of enterprises, managements and companies carrying air transportation, 
d) Procurement of goods or services and construction works of institutions of foreign administrations; goods or services purchases of the transport vehicles that are located abroad, required to be provided from their current locations,

e) Organizations covered by this Law such as; criminal execution institutions affiliated to the Ministry of Justice, detention houses, workplaces institutions, nursing homes and orphanages affiliated to the Social Services and Child Protection Institution, schools and centers that make production affiliated to the Ministry of National Education, institutes and production stations affiliated to the Ministry of Agriculture and Rural Affairs and the Prime Ministry Printing Office Administration products and services from the referred organizations; for goods and services located on State Supply Office Main Statute from the General Directorate of State Supply Office; for load, passenger and port services from the Republic of Turkey State Railways Administration; for fuel and vehicles from the General Directorate of Liquidation Affairs Circulating Capital Managements and purchases of the Directorate of Scientific and Technological research Council of Turkey made within the scope of their research and development activities for goods, works and consulting services, meat and meat products purchases from the General Directorate of Meat and Fish, for the mono block wheels and wheel sets used in the vehicles that pull and get pulled on the rail from the Directorate General of the Machinery and Chemical Industry Institution,

f) Purchases of all kinds of research and development services except for the purchases of goods and services required for the research and development projects carried out and supported by the national research and development institutions and circumstances in which the results obtained by an administration are used only for the execution of their own activities, if said administration is completely financed by an administration within the scope of the Law,

g) Within the framework of the commercial and industrial activities of the institutions listed in subparagraphs (b) and (d) of the first paragraph of the second article; purchases of goods or services that the approximate cost and contract value do not exceed two trillion and three hundred billion Turkish Liras, other than those financed by the Treasury guarantee or by transferring from the transfer mechanism of the direct budget, for their needs for direct production of goods and services or their main activities,

h) The procurement of diagnostic and therapeutic services to be provided to the right holders in accordance with their own legislation under the scope of this Law, and the procurement of medicines and medical supplies prescribed during the outpatient treatment of persons undertaken by their institutions, purchases of goods and services made for diagnosis and treatment purposes of the administrations from each other which provide health services and are within the scope of this Law,

i) Purchases of goods and services related to survey, restoration, restitution and conservation projects, street rehabilitation, landscaping projects and their applications, assessment, preservation, transportation and excavation works of movable and immovable cultural assets within the scope of the Law on Protection of Cultural and Natural Assets dated 21.7.1983 and numbered 2863,

j) Within the scope of the provisions of the Law on the Principles of Emergency Response and Compensation of Damages in the Contamination of the Marine Environment with Petroleum and Other Harmful Substances, the provision of services that may be urgently needed for the preparation of emergency response plans and the execution of emergency response plans after an incident has occurred and material purchase,

k) Repairs and restorations of foundation cultural assets and procurement of goods or services related to environmental planning,

1) Procurement of goods and services required for the implementation of protection measures to be taken in accordance with the provisions of the legislation on the protection of witnesses,

m) Spot liquedified natural gas (LNG) purchases to be made by Petrol Transport Co.Inc. (BOTAŞ) with pipelines through imports,

n) Procurement of services from Turkish Airlines Corporations for enlisted personnel and military material to be transported by air; procurement of goods and services of General Directorate of Turkey 
Radio and Television Corporation, for any program, news, production and broadcast made from Anadolu Agency Joint Stock Company; procurement of goods and services by making agreements or contracts that allow for prior assurances, in order to ensure immediate and effective delivery of urgent needs born from international obligations or for national purposes that may arise in situations such as defense, security, and humanitarian aid,

o) Energy, fuel, goods, services, consultancy procurements and major repair works provided by affiliated organizations of the Ministry of Energy and Natural Resources or related institutions or organizations, between each other or other public institutions, and electrical energy purchases by TETAŞ for supply purposes,

p) Procurement of goods and services related to international youth activities of the Ministry of Youth and Sports and national and international sports activities of the General Directorate of Sports and independent sports federations,

q) Within the scope of the Council of Ministers' decrees on providing coal aid to poor families; purchases of goods and services from coal fields belonging to Turkey Coal Enterprises General Directorate itself or its subsidiaries or affiliates, regardless of operators,

r) Procurement of goods or services to be made by General Directorate of The Republic of Turkey State Railways and the Republic of Turkey State Railways Transport Joint Stock Company, from Turkey Railway Machines Industry Joint Stock Company, Turkey Locomotive and Engine Industry Corporation and Turkey Wagon Industry Joint Stock Company,

s) Procurement of goods and services to be carried out from companies established or participated by the Directorate of Measurement, Selection and Placement Center (ÖSYM) (with the approval of the Higher Education Council) and the purchase of goods and services intended for examination purposes,

t) Procurement of goods and services that include industry participation practices to ensure innovation, localization and technology transfer can be counted.

Development Plans, especially for a certain period shaped by economic references; are documents that reflect both the understanding of the state and the public policies of the planned period, since they contain very important data about the social structure. For this reason, it is necessary to reveal what is foreseen in the country's development plans in subjects such as tender legislation, public tenders, technical consultancy and contracting, procurement of goods and services. Development Plans have been implemented for five year periods (Only the 9th Development Plan was for 7 years) since 1963. The most comprehensive of the strategic plans for public procurements, procurement of goods and services, '11th Development Plan, puts forward all institutional and structural arrangements of the public together with sustainable social, environmental and economic development goals. The plan aims to increase competition by reviewing public service provision in terms of organizations and methods and improving public procurement and contract processes to save public investment expenditures (Ministry of Development, 2019: 45). The main objective is to increase the resources related to public fixed capital investments, to rationalize the investment program, to use the allocated resources effectively and result-oriented, and to ensure compliance of the practices with macroeconomic policies (Ministry of Development, 2019: 102). The complementarity relationship between public investments and private sector investments will be deepened by investments into public infrastructure that will pave the way for investments into the private sector that create high added value, increase employment, and contribute to decreasing the current deficit. Compared to national income, the share allocated to public investments is aimed to be increased in the 11th plan period (Ministry of Development, 2019: 102).

Public investments will continue to be allocated in such a way as to reduce regional disparities and to assess the potential for regional development. In order to get the maximum benefit from the existing capital stock before developing new investment projects, the alternative to the maintenance-repair and rehabilitation expenditures related to the investments is among the topics to be evaluated (Ministry of Development, 2019: 103). It is stated that the public administrations will be responsible and authorized for developing common strategies regarding industrialization policies, determining the principles and procedures for developing special models related to public procurement, including making joint purchases in accordance with the 
determined models but also ensuring that different methods are applied as well. It has been committed to create the necessary budget resources and to use these resources effectively and efficiently in order to perform the determined tasks (Ministry of Development, 2019: 56). It is planned to implement new investment models with mechanisms that will include issues such as domestic equipment use, R\&D and technology transfer in the field of renewable energy in addition to public procurements (Ministry of Development, 2019: 86). The main objective is to make the construction sector a global brand abroad, by providing a human-oriented and environmentally friendly structure based on quality competition reliant on qualified supply and demand, and creating added value with its design and technological capabilities, and a high R\&D capacity. It is aimed to provide growth based on qualified supply and demand by integrating domestic and innovative technologies in the processes in the construction sector (Ministry of Development, 2019: 132).

It is envisaged to provide service procurements without compromising quality in the tenders related to the construction and technical consultancy works carried out by the public. It is stated that the necessary legislative preparatory works will be completed for domestic technical consultancy tenders which are based on local experience, and the technological compliance capacity will be strengthened, and the building control system will be improved. The private sector building contractors will be classified according to their economic and technical competencies, and the practice of proficiency in business sizes that they can undertake will be initiated, thereby protecting consumers and supporting firms with competence in the sector (Ministry of Development, 2019: 132). It is stated that trade policy tools will be used to undertake projects abroad in the contracting sector, and to establish partnerships with other companies that can contribute to our companies in terms of technological superiority, access to finance or market entry (Ministry of Development, 2019:132). According to the data of the Ministry of Commerce in 2018, the annual total project amount of the technical consultancy services abroad was 166 billion dollars in 2018, in view of the 11th Development Plan estimates; it has been announced that this number will increase to 225 billion dollars in 2023 and support of foreign consultancy companies' technical activities will continue (Ministry of Development, 2019:132). Similarly, while the international contracting services business volume was 20.8 billion dollars in 2018, this figure is expected to be 35 billion dollars in 2023. It is stated that in order for foreign contracting services to enter new markets, to deepen in existing markets, to contribute to the export of Turkish construction products, companies will continue to be supported in positioning, strengthening and branding in international markets, and also the development of foreign contracting and technical consultancy services will continue to be supported (Ministry of Development, Ministry of Development, 2019:132). These are the steps to support both the economic structure of the population of this period of the country and the economic improvements, sustainability and economic development related to the prosperity period that future generations will experience, by implementing all these improvement policies regarding economic life.

\section{Conclusion and Evaluation}

It is seen that up to date, public procurement legislation for the realization of public procurements, which constitute the majority of public expenditures has been regulated by four laws. The first law was numbered '661' in 1925. Auction, Debate and Import Law', then respectively; the Auction and Reduction Law No. 2490 in 1934, the Public Procurement Law No. 2886 in 1983 and finally the Public Procurement Law No. 4734 and the Public Procurement Contracts Law No. 4735, dated 2002 which are still in use.

'Tenders of Construction Works Implementation Regulation', 'Tenders of Procurement of Goods Application Regulation', 'Tenders of Service Procurement Application Regulation', 'Tenders of Consultancy Service Procurement Application Regulation' and 'Regulation on Administrative Applications against Tenders' were prepared as the implementation regulations of the said Laws and came into force. However, the scope of the Public Procurement Law No. 4734 is narrowed and constantly changed. It is usual for a law to change along the needs axis during execution, but the number of changes and narrowing of the scope in the tender law is unusual. Looking at examples from the past, the law needs to change and the scope should narrow in the medium term according to enforcement needs, and in the long term a new complementary and up-to-date law should be prepared. Because with the proper operation of tender laws,

- It will be possible to ensure the efficient use of national resources.

- Finishing the works related to public spending on time and performing them healthily; will provide economic gains in both time and resource usage. 
- Improvements in procurement laws will support the development of the country and the increase of welfare.

- In this context, the profitable operation of tender laws will contribute to the sustainable economic development of the country.

- Sustainable economic development and improvement provided; will affect both the living standards of this generation and the living standards and social well-being of the next generations.

- By ensuring this, the desired level of economic prosperity, development goals and developed country standards in the country will be achieved in an ideal way and intergenerational economic development parameters will be diversified.

In the laws that came into force; targets such as transparency in tenders, competitive participation, equal treatment, confidentiality principle, reliability in tenders, efficient use of resources, ensuring adequate public control, meeting the needs under appropriate conditions and on time have been aimed. Ability of procurement laws to meet country development parameters along with economic life; affects not only the economic life but also the quality of the entire social life.

Politicians and planners that direct the principles of development and balance the tensions by triggering the initiatives are increasingly responsible for the healthy operation of the conceptual and applicational areas of the tender laws that give life to economic life each passing day. Tender laws and economic effects that cover a large part of the country's development strategies and support economic sustainability; have a daily increasing need for more rational innovations, integration into international laws and norms, development of control mechanisms and competitive markets since it affects both the period it is applied and the next generations.

\section{References}

[1.] Altuntaş, A. (2012). Sürdürülebilir Toplumlar ve Metropollerin Baskılarından Kurtulmak İçin Alternatif Bir Yol: Sürdürülebilir Kentler, Mustafa Kemal Üniversitesi Sosyal Bilimler Enstitüsü Dergisi, 9 (17):135-148.

[2.] Atıl, A., Gülgün, B. ve Yörük, İ. (2005). “Sürdürülebilir Kentler ve Peyzaj Mimarlığı”. Ege Üniversitesi Ziraat Fakültesi Dergisi, İzmir, 42(2):215-226.

[3.] Benkari, N. (2013). “The 'Sustainability' Paradigm in Architectural Education in UAE”, Procedia Social and Behavioral Sciences, 102: 601-610.

[4.] Bruntland Report, (1987). Web: https://sustainabledevelopment.un.org/content/documents/ 5987our-common-future.pdf, Date of Access:13.02.2020.

[5.] Çetinkaya, Ö, Filibe, M. ve Üstün, K. (2018). “Tarihsel Boyutu ile Kamu Alım Usullerindeki Gelişmeler ve Günümüzdeki Yapının Değerlendirilmesi”, Marmara University Journal of Political Science, İstanbul, 6(1): 311-330.

[6.] Goodland, R. (1995). "The Concept of Environmental Sustainability", Annual Review of Ecology and Systemaics, 26, 1-24.

[7.] Holmberg, J. and Sandbrook, R. (1992). "Sustainable Development: What Is to Be Done?" Making Development Sustainable: Redefining Institutions, Policy and Economics (Ed. J. Holmberg). International Institute for Environment and Development, p.19-38, Island Press, Washington D.C.

[8.] Kanca, O.C. ve Bayrak, M. (2015). "Ekonomik Tasnif Esasında Türkiye'de Kamu Harcamaları", Muş Alparslan Üniversitesi Sosyal Bilimler Dergisi, Muş, 3(1):107-139.

[9.] Karakurt Tosun, E. (2009). “Sürdürülebilirlik Olgusu ve Kentsel Yapıya Etkileri”, No:2, Paradoks.

[10.] Karakurt Tosun, E. (2013). "Sürdürülebilir Kentsel Gelişim Sürecinde Kompakt Kent Modelinin Analizi”, Yönetim ve Ekonomi, 20 (1): 31-46.

[11.] İğdeler S. (2003). “Kamu İhale Kanunu: Yenilikler ve Eksiklikler”, Erişim adresi: http://www.tid.gov.tr/ Makaleler/1-38.DOC. 
[12.] İhale Mektebi, Erişim adresi: https://ihalemektebi.wordpress.com/mevzuat/cumhuriyet-donemiihale-kanunlari-tarihi/661-sayili-muzayede-munakasa-ve-ihalat-kanunu/.

[13.] Official Gazzette No: 661, Official Gazzette Date of Publication: 28.04.1925, No: 97.

[14.] Official Gazzette No: 2490, Official Gazzette Date of Publication: 10.06.1934, No: 2723, Accessed Address: http://www.resmigazete.gov.tr/arsiv/2727.pdf.

[15.] Official Gazzette No: 2886, Official Gazzette Date of Publication: 10.09.1983, No: 18161, Accessed Address: http://www.mevzuat.gov.tr/MevzuatMetin/1.5.2886.pdf.

[16.] Official Gazzette No: 4734, Official Gazzette Date of Publication: 22.01.2002, No: 24468, Accessed Address: http://www.resmigazete.gov.tr/eskiler/2002/12/20021209.htm.

[17.] Official Gazzette No: 4735, Official Gazzette Date of Publication: 22.01.2002, No: 24468, Accessed Address: http://www.resmigazete.gov.tr/eskiler/2002/12/20021209.htm.

[18.] Türkiye Büyük Millet Meclisi, Danışma Meclisi. (1981). "Devlet İhale Kanunu Tasarısı ve Bayındırlık, Ulaştırma, İmar ve İskân, Turizm ve Tanıtma ve İktisadî İşler Komisyonu Raporu”. Accessed

Address: https://www.tbmm.gov.tr/tutanaklar/TUTANAK/DM_/d02/c020/dm_ 02020135ss0483 .pdf.

[19.] TBMM, (2001). "Kamu İhale Kanunu Tasarısı ve Plan ve Bütçe ve Bayındırlık, İmar, Ulaştırma ve Turizm Komisyonu Raporu”. Accessed Address: https://www.tbmm.gov.tr/tutanaklar/TUTANAK /TBMM/d21/c082/tbmm 21082047ss0794. Pdf.

[20.] TBMM, (2003). "Bazı Kanunlarda Değişiklik Yapılması Hakkında Kanun Tasarısı İle Kamu İhale Kanunu ve Kamu İhale Sözleşmeleri Kanununda Değişiklik Yapılması Hakkında Kanun Tasarısı; Benzer Mahiyetteki Kanun Teklifleri ve Bayındırlık, İmar, Ulaştırma ve Turizm Komisyonu Raporu". Accessed Address: https://www.tbmm.gov.tr/tutanaklar/TUTANAK/TBMM/ d22/c025/tbmm22025113ss0257.pdf.

[21.] T.C. Türkiye Cumhurbaşkanlığı Strateji ve Bütçe Başkanlığı, (2019). "Eleventh Development Plan (2019-2023)”, Ankara: Cumhurbaşkanlığı. Web: http://www.sbb.gov.tr/kalkinma-planlari/.

[22.] UNESCO-MOST, (1996). "Conference Report on Sustainability as a Social Science Concept", Frankfurt.

[23.] Yilmaz, B. M. (2007). “Kamu Alımlarında İdari Denetim”, Yetkin Yayınevi, Ankara. 